\title{
Designing Blended Learning for Teaching English Grammar at Higher Education
}

\author{
I Made Sujana* \\ English Education Department \\ University of Mataram \\ Mataram Indonesia \\ madesujana@unram.ac.id \\ A Arifuddin \\ English Education Department \\ University of Mataram \\ Mataram Indonesia \\ email address
}

\author{
Edy Syahria \\ English Education Department \\ University of Mataram \\ Mataram Indonesia \\ edysyahrial@unram.ac.id \\ Lalu Thohir \\ English Education Department \\ University of Mataram \\ Mataram Indonesia \\ thohir@unram.ac.id
}

\begin{abstract}
The mastery of English Grammar for Students of English Education Department (henceforth EED) has a multipurpose target, namely, to build their confidence in communication (both spoken and written), to prepare them to be English teachers, who need English grammar for teaching, and to meet their graduation requirement on the TOEFL score, one section of which demands a high level of grammar mastery. Thus, the series of English Grammar courses are expected to equip them with those competencies. However, based on some research findings and observations, students' grammar mastery is still far from the aforementioned purposes. This research aims at redesigning the teaching of English Grammar using Blended Learning by combining face-to-face and online learning. This is a part of a longitudinal study employing the development framework of Blended Learning proposed by GIHE (2010). The data were collected using triangulation techniques (document, questionnaire, and interview) involving EED lecturers, $2^{\text {nd }}$ semester students and analyzed descriptively. The results showed that the design of Blended Learning integrates Consciousness-Raising (C-R) Model for face-to-face mood and Google Classroom platform for online mood. Both online and F2F materials were made parallel with slightly different contents. Each unit systematically consists of Learning Objectives $\wedge$ Pre-Test $\wedge^{\wedge}$ Materials Presentation ${ }^{\wedge}$ Exercises (for each sub-topic) ${ }^{\wedge}$ Self Assessments and Reflection on Learning $\wedge$ Post Test. Students responded positively to the design of Blended Learning using C-R Model and Google Classroom in terms of ease of access, usefulness, and students' satisfaction.
\end{abstract}

Keywords-Blended Learning, Google Classroom, English Grammar, face-to-face, online, C-R Model

\section{INTRODUCTION}

The importance of teaching English grammar in second and/or foreign language learning has long become heated debates among theorists and practitioners of ELT. On one side, it is argued that the teaching of grammar does not contribute to learners' development in authentic communication [1] since grammar can be learned naturally in meaning-based communication involvement [2]. Those opinions, however, are refuted by some experts [3]-[5] by stating that the teaching of grammar helps to master a second language. White (1987) states that some aspects of grammar cannot be taught only by input but need to be taught directly. Ellis [4] added that through formal learning the learner becomes "aware" of the grammatical structure and once awareness arises, this ability will continue to persist. Leachtenauer [8] in line with Ellis [4] emphasized that grammatical elements not only need to be taught but also that learning must also go through an active process of learners through consciousness-raising tasks. Without awarenessraising activities (CR) learners will never learn optimally.

For the students of the English Education Department, English grammar is needed for several purposes. It is required for (1) building accuracy in communication skills (both spoken and written); (2) preparing to be English teachers, who may need to explain English grammar to their learners; and (3) meeting a graduation requirement, which requires a TOEFL score of 500 .

However, several studies have shown that the ability of EG of senior students in English Language Education, UNRAM on average is still relatively low both as illustrated in lectures on language skills that require the application of English Grammar skills and in working on questions on the TOEFL test [9]-[12]. It is also supported by the latest research conducted by Sujana, et al. (2018) which found that the average ability of students in semester IV of English Language Study Program UNRAM in TOEFL Structure \& Written Expression (SWE) was 452.01 with a range score of 330-620. These data showed a very high gap between able students and less able students. With this ability, it is predicted that students will experience various obstacles both in using English to communicate, in carrying out their duties as a teacher (practice), and in fulfillment of graduation requirements.

The present study is directed to redesigning the teaching of English grammar series by combining traditional teaching (face-to-face) and online mode, commonly called Blended Learning (BL). BL refers to a systematic integration of traditional (face-to-face) learning and online learning [13][16]. In the teaching of Elementary English Grammar in this research, the integration is made between Consciousness Raising Model (CRM) for face-to-face and Google Classroom for online learning. CRM is a model of learning English Grammar by encouraging learners to deliberately learn the language forms or structures of the target language [17],[18]. Google Classroom is a free online learning application designed in the field of education to help learners and 
educators communicate, collaborate, organize and manage material, assignments, questionnaires, etc. paperless [19],[20].

\section{METHOD}

This research developed Elementary English Grammar learning materials by combining Consciousness -Raising Model for F2F learning materials and Google Classroom for online learning. The materials were then tested in Elementary English Grammar lectures. The development framework used in this research was the development of Blended Learning suggested by GIHE [21] which includes (1) Planning, (2) Designing, (3) Implementing, (4) Reviewing, and (5) Improving.

The data were collected from lecturers teaching English Grammar and 54 students of the English Education Department, the University of Mataram registered in
Elementary English Grammar by using a triangulation technique such as observation, questionnaire, and Focus Group Discussion (FGD). The data were then analyzed qualitatively.

\section{RESULT AND DISCUSSION}

Following the development framework mentioned above, for fulfilling face-to-face and online learning materials required in the Blended Learning model, the current printed materials of Elementary English Grammar (EEG) are integrated into an online platform called Google Classroom (GC). The integration is intended to achieve effective and efficient learning and provide learners with materials needed for structured assignments and independent study as required by the National Standard of Higher Education (known as SNDIKTI) [22] related to learning workload.

\section{BLENDED LEARNING}

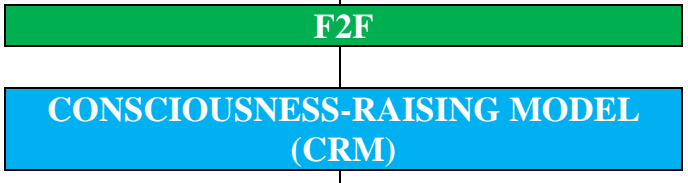

1. Learning Objective \& Indicators

2. Pre Test

3. Materials Presentation and Exercises

4. Self Assessment \& Reflection on

Learning

5. Post Test

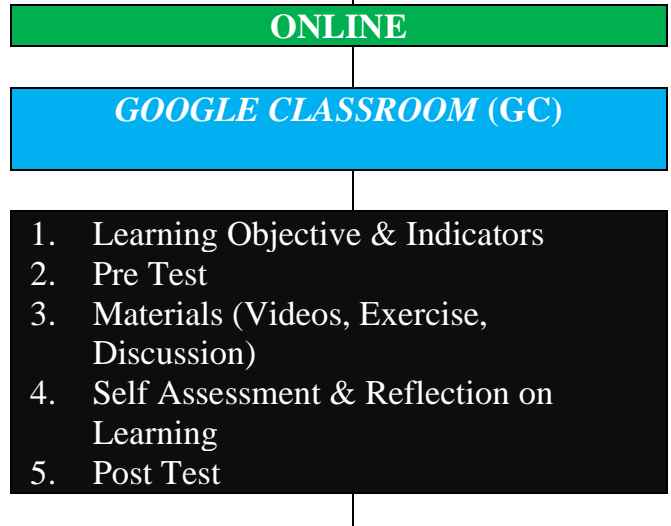

Improvement of EG competency, participation, optimizing resources, learning independence, $4 \mathrm{C}$ in P21

Fig. 1. Skeleton of Blended Learning design in teaching English Grammar

\section{A. Design for Face-to-Face Learning}

The learning outcome of teaching Elementary English Grammar for students of English Education, the University of Mataram is to be able to use English Grammar needed for both presenting high school structure materials and coping with their study (communication both spoken and written) [23]. The Learning Outcome is broken down into five Learning Objectives, that is, ability to use (1) various sentences using modifiers; (2) various forms of passive voice; (3) various forms of degrees of comparison; (4) various forms of adverbial clauses; and (5) various forms of conditional sentences and wish. The Learning Objectives are further developed into Achievement Indicators and Teaching Materials.

To support face-to-face learning, each competency (unit) is developed in a systematic way following sequences: (a) Learning Objective and Achievement Indicators; (b) Pre-Test, to check learners' entry behavior on this topic; (c) Descriptions of learning materials followed by exercises, based on the Achievement Indicator; (d) Self-Assessment; (e) Reflection on Learning; and (f) Post Test with its purpose.
Below is the sample of the development of face-to-face materials:

TABLE I. SAMPLES OF THE DEVELOPMENT OF PRINTED LEARNING MATERIALS FOR EEG

\begin{tabular}{|l|l|}
\hline UNIT 1 MODIFIERS & UNIT 2 PASSIVE VOICE \\
\hline Learning Objective \& Indicators & Learning Objective \& Indicators \\
Pre-Test & Pre Test \\
Modifiers & Passive Voice \\
Relation of Verb and Adverbs in & Forming and Using Passive \\
Tenses; & Passive with "be" \\
Word Order of Adjectives Phrases; & Passive with Modals \\
Adjective vs. Adverb of Manner; & Passive with "Get" \\
Linking Verbs and Adjectives; & Special Passive Pattern \\
Participles as Adjectives; & Stative Passive \\
The Use of So vs. Such; & Passive with Infinitive and Gerund \\
Nouns functioning as Adjectives & Self-Assessment \& Reflection on \\
Self-Assessment \& Reflection on & Learning \\
Learning & Post Test \\
Post Test & \\
\hline
\end{tabular}

To provide learners with learning processes, each section or sub-unit is equipped with an explanation of concepts and exercises for both class meetings and individual exercises outside the class.

\section{B. Design for Online Learning}


Online learning is developed using Google Classroom, the free online learning platform issued by Google Inc. Of four classes, they were divided into 2 parallel-online classes to avoid connection problems on accessing materials and tests.

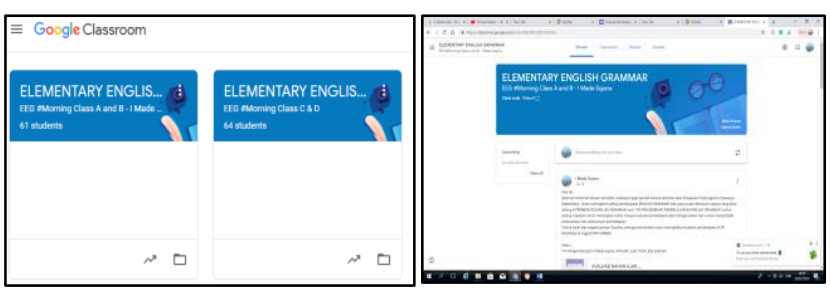

Fig. 2. Google Classroom for teaching English Grammar

The materials or contents on Goole Classroom were designed based on the competency on Face-to-Face materials, consisting of Modifiers, Passive Voice, Degrees of Comparisons, Conditional Sentences, and Adverbial Clauses in Complex Sentences. Each unit/competency was designed as seen into several sections parallel to F2F contents such as Pre Test, Learning Objectives, Materials consisting of videos, exercises, handout, PowerPoint, etc., Self Assessment and Reflection on Learning, and Post Test, as presented in Picture 3 below.

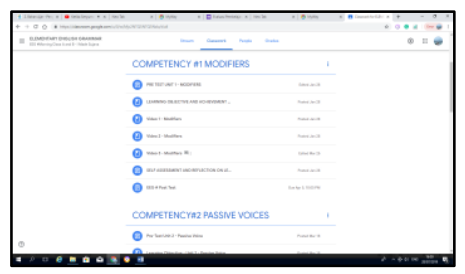

Fig. 3. Sample of contents of each unit in Google Classroom

The Pre-Test on this online is taken from the core book used in the printed material. It is intended to check students' entry behavior on the related topic. The students are assigned to do it at home before learning the respective unit to save time for the class meetings. Upon completing the Pre-Test, the students are expected to read Learning Objective and Achievement Indicators presented both online and on the printed materials as a guideline for competency achievement. It is intended to raise learners' awareness of competencies to be achieved. Learning Materials consist of videos, additional materials, and exercises. To check students' understanding, GC is also provided with Self-Assessment and Reflection on Learning by writing Mind-Mapping. At the end of this unit, the students are assigned to complete the online Post-test, which is also taken from the printed materials with or without modification for both practice (assessment for learning) and achievement (assessment of learning). The use of online Pretest and Post-test saves time for material discussed in class meetings.

TABLE II. SAMPLE OF DEVELOPMENT OF THE ONLINE LEARNING PROGRAM FOR EEG

\section{UNIT 1 MODIFIERS UNIT 2 PASSIVE VOICE}

\begin{tabular}{|l|ll|}
\hline 1. & $\begin{array}{l}\text { Learning Objective \& \& } \\
\text { Indicators }\end{array}$ & $\begin{array}{l}\text { Learning Objective \& } \\
\text { Indicators }\end{array}$ \\
2. Pre-Test & 2. & Pre Test \\
3. Modifiers & 3. & Passive Voice \\
a. PPT - Modifiers & & a. PPT \\
b. Video 1 & b. Video 1 \\
c. Video 2 & c. Video 2 \\
d. Video 3 & d. Video 3
\end{tabular}

\section{UNIT 1 MODIFIERS UNIT 2 PASSIVE VOICE}

\begin{tabular}{|ll|ll|}
\hline e. Additional Exercises & e. Additional Exercises \\
4. $\begin{array}{l}\text { Self Assessment } \\
\text { Reflection on Learning }\end{array}$ & 4. $\begin{array}{l}\text { Self-Assessment \& } \\
\text { Reflection on Learning }\end{array}$ \\
5. $\begin{array}{l}\text { Post Test } \\
\text { Post Test }\end{array}$ \\
\hline
\end{tabular}

The role of online learning (Google Classroom) in the teaching and learning process of EEG is to support, not to replace, the class meetings. It is intended for providing students with materials needed to support the class meeting with extended materials such as additional printed and nonprinted materials (videos, online tests, and assignments, etc.). The idea is in line with students' workload for a two-credit course as stated in Permenristekdikti 44/2015.

The design of the Blended Learning Model is then implemented in EEG classes, participated by 106 students of EED UNRAM divided into 4 classes, involved three lecturers. Here are the students' perceptions of both F2F and online materials and implementation.

\section{Students' Perception of Face-to-Face Materials}

Here is the result of students' perception of the design of printed materials related to the level of difficulty, organization, fulfillment of students' needs, the role of exercises, and assessment.

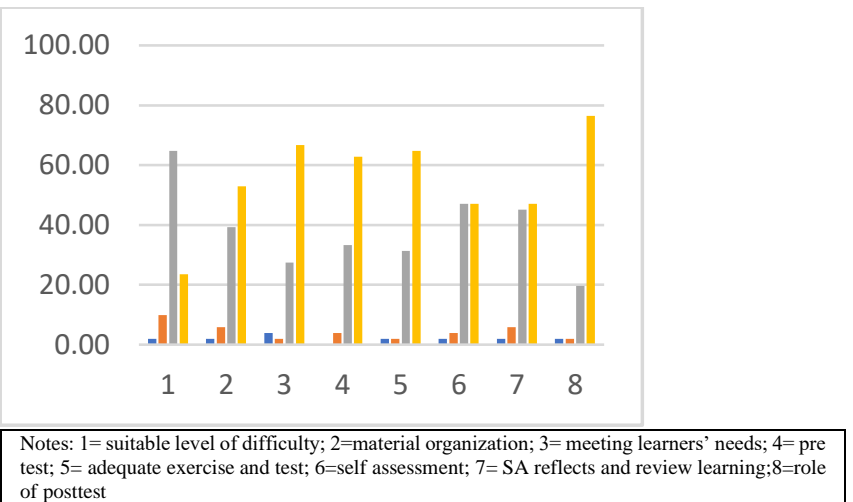

Fig. 4. Face to Face Materials

Fig. 4 showed that students responded positively to all aspects of face-to-face materials being investigated. The positive responses were given in terms of the level of difficulty $(88.24 \%)$, organization $(92.16 \%)$, and fulfillment of needs for teaching preparation and communication (94.12\%). Related to practices and assessment, students commented that the printed materials provided them with the pre-test to check their entry behavior (96.08\%) and post-test to check their progress $(96.08 \%)$, the chance to monitor their learning through self-assessment and reflection on learning (94.12\%).

\section{Students' Perception of Google Classroom}

Students' perception of the use of Google Classroom in teaching EEG in terms of ease of access, usefulness, students' satisfaction is presented in the following tables. 


\section{Ease of Access}

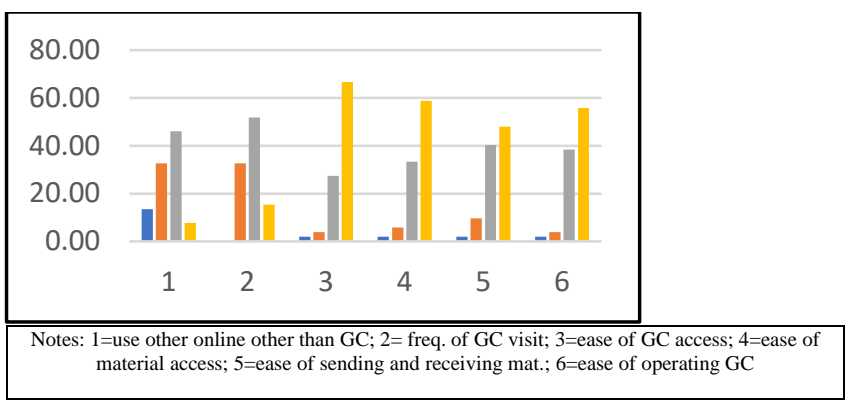

Fig. 5. Ease of Access

Students gave positive responses to the use of Google Classroom as an online learning platform in the teaching of English Grammar in terms of its ease of access. Most students admitted that Google Classroom was easy to access (94.12\%), easy to send and receive materials and test $(88.46 \%)$, and easy to operate for learning (94.23\%). The positive response on the ease of access to the use of GC is also supported by the results of open-ended questions.

\section{Usefulness}

The graph below shows students' responses to the use of GC in the teaching and learning process of Elementary English Grammar

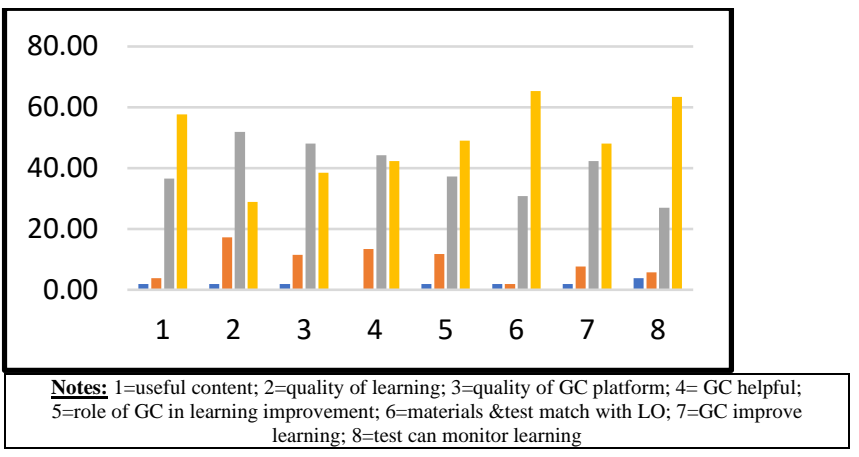

Fig. 6. Usefulness of GC

In terms of its usefulness, most students also responded positively to the use of Google Classroom in teaching Elementary English Grammar. Students considered GC a useful platform concerning its content $(94.23 \%)$, quality of learning activity (80.77\%), exercises (86.27\%). The application of GC was also regarded as useful to improve students' learning (90.38\%) and to monitor students learning through Pre-test and Post Test (90.38). The results were also in line with those of open-ended questions.

\section{Students' satisfactions}

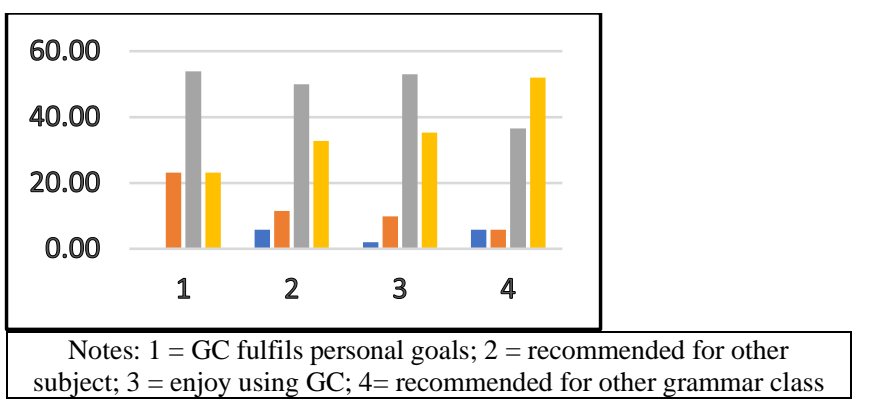

The graph above also showed that the students registered in EEG responded positively to satisfaction in using GC. Most students felt that GC can fulfill their personal goals (77.3\%) and that they enjoyed their learning $(88.23 \%)$ so that they would recommend the use of GC for other grammar classes and other subjects.

To sum up, from the findings mentioned above, the teaching of EEG was designed using Blended Learning by combining the Consciousness-Raising Model for face to face and Google Classroom for online learning. Both F2F and online materials were made parallel with slightly different contents such as the use of videos for materials enrichment and variation and Google Forms for tests and assignments. The use of GC was not intended to replace class meetings, but rather as the support of learning for both in- and out-class activities. The application of Blended Learning in this class could fulfill the student learning workload. The learning workload for a 2-credit course is 100 minutes for class, 120 minutes for structured activity, and 120 minutes for independent learning [22]. Besides, the application of BL can support formal meetings to individualize learning, improve learning activity and creativity [20], [24], [25].

Most students responded positively to the application of Blended Learning in the teaching of EEG from the point of view of ease of access, usefulness, and satisfaction. As an online learning platform, Google Classroom was managed directly by Google Inc. so that they suggested that GC be used for other grammar classes and other subjects. This finding is in line with the opinion stating that GC is easy to use, quick to set, quick and safe to share and store documents [19], [20].

\section{CONCLUSION}

This article has explored the design of Blended Learning and students' perception of the application of the Blended Learning in teaching Elementary English Grammar (EEG) for students of EED UNRAM. The design combines the use of Consciousness-Raising Model for face-to-face learning and Google Classroom for online learning. Both F2F and online learning are made parallel in terms of contents with slight differences on main material in which GC uses videos and online Google Forms for testing and giving the assignment.

Students perceive positively to the printed and online materials using GC. Most students consider that F2F materials in terms of level of difficulty, organization, fulfilment of needs, and assessments are suitable for their present situtations. The use of GC also obtains positive responses in relation to ease of access, usefulness, and satisfaction.

\section{REFERENCES}

[1] Krashen, S. (1999). Seeking a role for Grammar: review of some recent studies. Foreign Language Annals , 32 (2), 245-254.

[2] Prabhu, N. (1987). Second Lnguage Pedagogy. Oxford: Oxford University Press.

[3] Celce-Murcia, M. (1992). Formal Grammar Instruction. TESOL Quaterly 36 (2), 406-409.

[4] Ellis, R. (2002). Does form-focused instruction affect the acquisition of implicit knowledge? A review of the research. Studies in Second Language Acquisition, 24, 223-236.)

[5] White, L. (1987). Against Comprehensible Input: The Input Hypothesis and the development of second language competence. Applied Linguistics , 8, 96-110

Fig. 7. Students Satisfaction 
[8] Leachtenauer, J. (2004). Teaching Grammar through Grammar Consciousness-Raising Tasks. Journal of Inquiry and Research , 80, 111.

[9] Arifuddin, \& Sujana, I. M. (2004, February). Kecakapan Berbahasa Inggris Mahasiswa Senior PS Pendidikan Bahasa Inggris LPTK di Nusa Tenggara Barat. Jurnal Penelitian University of Mataram 3(20), 1-15..

[11] Septiansyah, A. (2017). An Analysis of Problems Faced by Senior Students in SWE Section of TOEFL. Mataram: the University of Mataram.

[12] Sujana, I. M., Syahrial, E., \& Fitriana, E. (2003). Analisis Permasalahan Mahasiswa Senior PS Pendidikan Bahasa Inggris FKIP UNRAM dalam TOEFL. Jurnal Penelitian University of Mataram , 2

$$
\text { (3), } 1-16
$$

[13] Bonk, C. J., \& Graham, C. R. (2006). Handbook of Blended Learning: Global Perspektif, Local Design. San Fransisco, CA: PfeifferPublishing.

[14] Kaur, M. (2013). Blended Learning : its challange and future. Procedia: Social and Behavioral Sciences, 39, 612-617.

[15] Whittaker, C. (2013). Introduction. In B. Tomlinson, \& C. Whittaker, Blended Learning in ELT: Course Design and Implementation. London: British Council.

[17] Ellis, R. (2005). Grammar Teaching - Practice or Conciuos-Raising? In J. C. Richards, \& W. A. Renandya,

[18] Richards, J. C., \& Schmidt, R. (2010). Longman Dictionary of Language Teaching \& Applied Linguistics (Vol. 4th edition). Great Britain: Pearson Education Ltd.

[19] Keeler, A., \& Miller, L. (2015). 50 Things You Can Do with Google Classroom. San Diego, CA: Dave burgess Consulting Inc.

[20] Bell, K. (2015). The Teacher's Guide to Google Classroom. ni: Shake Up Learning, LLC.

[21] GIHE. (2010). Getting Started with Blended Learning. Griffith: Griffith University.

[22] Kemenristekdikti. (2015). Permenristekdikti RI No 44 Tahun 2015 tentant Standar Nasional Pendidikan Tinggi. Jakarta: Kemenristekdikti.

[23] Sujana, I. M. (2018). English Grammar 2. Mataram: Arga Puji Press.

[24] Heggart, K. R., \& Yoo, J. (2018). Getting the Most form Google Classroom: A Pedagogical Framework for Tertiary Educators. Australian Journal of Teacher Education , 43 (3).

[25] Jakkaew, P., \& Hemrungrote, S. (2017). The Use of UTAUT2 Model for Understnding of Student Perceptions using Google Classroom: A Case Study of Introduction to Infromation Technology Course. Digital, Arts, Media and Technology (ICDAMT) International Conference, (pp. 205-209). 